\title{
Rough Justice? \\ Exploring the Relationship between Information Access and Environmental and Ecological Justice Pertaining to Two Controversial Coastal Developments in North-east Scotland ${ }^{1}$
}

\author{
Graeme Baxter \\ Robert Gordon University
}

\begin{abstract}
This paper explores the relationship between information access and environmental and ecological justice through an historical comparison of two controversial coastal developments in Aberdeenshire, North-east Scotland: the building of a North Sea gas reception terminal by the British Gas Council and the French exploration company Total Oil Marine in the 1970s; and the more recent construction of 'the greatest golf course anywhere in the world' by the American property tycoon, Donald Trump. These two projects have much in common, not least because each one has had actual or potential impacts on an environmentally sensitive site, and because each has also been affected by plans for another major structure in its immediate vicinity. But the Trump golf course project has taken place during a period when access to information and citizens' influence on major planning decisions in Scotland has been significantly greater, at least in theory. With these points in mind, the paper considers whether or not environmental justice (more specifically, procedural environmental justice) and ecological justice are now more attainable in the current era of supposed openness, transparency and public engagement, than in the more secretive and less participative 1970s. It reveals that, at the planning application stage, information on the potential environmental impact of Trump's golf resort was more readily obtainable, compared with that provided by the Gas Council and Total forty years earlier. However, during and after the construction stage, when considering whether or not the developments have met environmental planning conditions - and whether or not ecological justice has been done - the situation with the gas terminal has been far clearer than with Trump's golf resort. Despite the golf course being built in an era of government openness, there remain a number of unanswered questions concerning its environmental impact.
\end{abstract}

\section{Introduction}

This paper examines the relationship between information access and environmental and ecological justice through an historical comparison of two controversial coastal developments in Aberdeenshire, North-east Scotland: the building of a North Sea gas reception terminal by

\footnotetext{
${ }^{1}$ This paper is based on a presentation made at the $24^{\text {th }}$ Annual Conference of the UK Socio-Legal Studies Association, Aberdeen, 9-11 April 2014. 
the British Gas Council (a public body) and the French exploration company Total Oil Marine in the 1970s; and the more recent construction of 'the greatest golf course anywhere in the world' (Kirk 2006) by the American property tycoon, Donald Trump. Figure 1 shows the location of the two developments. Although their construction is separated by 40 years, these two coastal projects have much in common, not least because each one has had potential or actual impacts on an environmentally sensitive site, and each has also been affected by plans for another major structure in its immediate vicinity (in the case of the gas terminal, this was a military radio station; in the case of the golf course, an offshore windfarm).

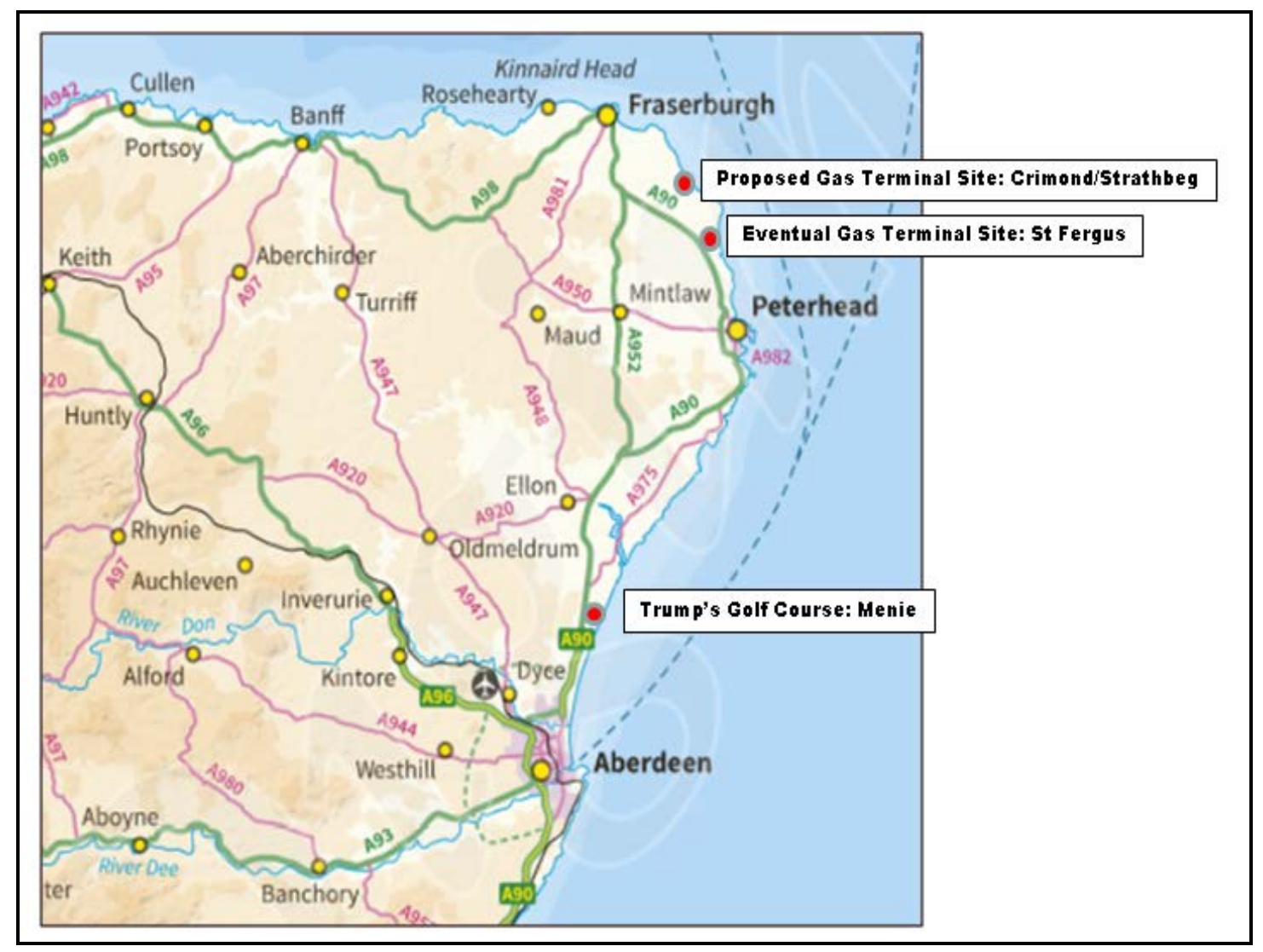

Figure 1: Location of gas terminal and golf course developments in North-east Scotland () Crown Copyright/database right 2013. An Ordnance Survey/EDINA supplied service)

At first glance, the paper may appear rather parochial, focusing as it does on two projects only a few miles apart in North-east Scotland, however, the issues it discusses are illustrative of the country-wide developments in public engagement and government openness that have taken place over the past four decades in Scotland. The Trump golf course project has taken place during a period when access to information and citizens' influence on major planning 
decisions in Scotland has been significantly greater, at least theoretically. With these points in mind, in comparing these two coastal developments, this paper investigates whether or not environmental justice (more specifically, procedural environmental justice) and ecological justice are now more readily attainable in this current era of supposed openness, transparency and public engagement, than in the more secretive and less participative 1970s.

The paper begins by providing a brief overview of the concepts of environmental and ecological justice, before moving on to discuss Scotland's environmental justice movement and its current openness and transparency regime. It then provides an account of the building of the gas terminal in the 1970s, concentrating on issues relating to information access and to environmental and ecological justice. It proceeds to do the same with the Trump development to date, comparing and contrasting the situation with that occurring over 30 years earlier, before concluding with some initial observations on the relationship between access to information and environmental and ecological justice. The paper is derived largely from desk-based research in which the author has collected data from a wide range of primary and secondary sources, including: local, devolved and national government archives; records of the developers; environmental interest group archives; academic and trade literature; and print and broadcast press coverage of the two projects.

\section{Environmental and ecological justice}

The concept of 'environmental justice' is regarded by many commentators as having emerged in the United States in the period between 1978 and 1982, when the state authorities in North Carolina chose to locate a landfill site for the burial of hazardous waste in Warren County, where the residents were primarily poor and African-American (e.g., McGurty 1999; Faber \& McCarthy 2001; Pezzullo 2001). In subsequent years, much of the discourse on environmental justice (and injustice) in the US focused on the disproportionate distribution of environmental hazards — such as toxic landfill sites and chemical plants — in minority and low-income communities (Stephens 2003). As Bullard (1999, p. 284) stated bluntly:

\footnotetext{
'All communities are not created equal. Some communities are more equal than others. If a community happens to be poor, working class, or inhabited largely by people of color, it has a good chance of receiving less protection than its affluent or mostly white counterpart. The nation's environmental laws, regulations, and policies are not applied uniformly which results in some individuals, neighborhoods, and communities being exposed to elevated health risks.'
} 
In 2004, Schlosberg noted that, globally, most theoretical understandings of environmental justice remained tied solely to the issue of inequity in the distribution of environmental ills and benefits. More recently, however, he has observed a broadening and deepening discourse that has moved beyond this distributive interpretation of environmental justice (Schlosberg 2007; 2013). In these works, Schlosberg categorises three additional, multifaceted and interrelated 'conceptions' or 'notions' of environmental justice:

- Recognition. Where recognition of, and respect for, various communities, identities and cultures affected by environmental risk are integral elements of justice.

- Capabilities. Where justice is considered in terms of the extent to which environmental policies and decisions restrict or enhance the basic functioning of individuals and communities.

- Participation and procedural justice. Where the construction of inclusive, participatory decision-making institutions is at the centre of environmental justice demands; where policymaking procedures institutionalise and encourage active public participation, and recognise local community knowledge.

Given that the current author's research has focused on the extent to which citizens were informed about, and could participate in, the planning processes surrounding the development of two sparsely populated and environmentally sensitive coastal sites, it is with the last of these notions - procedural environmental justice - that much of this paper is concerned. Equally, though, this paper considers the concept of ecological justice in relation to the two coastal developments. Baxter (2000) attributes the coining of the term 'ecological justice' to Low and Gleeson, who defined it as the 'justice of the relationship between humans and the rest of the natural world' (Low and Gleeson 1998, p. 2), and who further declared:

'The first principle of ecological justice is that every natural entity is entitled to enjoy the fullness of its own form of life. Non-human nature is entitled to moral consideration.' (Low and Gleeson 1998, p. 156)

Parris et al. (2014, p. 71), meanwhile, define ecological justice as the 'extent to which human activity treats the natural world with respect and dignity to insure the well-being of nonhuman species, flora, and the physical landscape'. Drawing on these definitions, this paper 
considers ecological justice in terms of the extent to which the environmental planning conditions attached to the gas terminal and golf course projects were met by the respective developers, and, by extension, the ways in which the flora, fauna and landforms were protected, maintained or restored during and after the construction phases of the two developments.

\section{Environmental justice and information access in Scotland}

Environmental justice first emerged as a concept in Scotland in 1999, when Friends of the Earth Scotland (FoES) launched a campaign to coincide with the inauguration of the new Scottish Parliament ${ }^{2}$. FoES's initial understanding of environmental justice linked classbased environmental maldistributions in Scotland with global inequalities in the consumption of ecological resources (Scandrett, Dunion \& McBride 2000). The first official recognition of environmental justice in Scotland came in a 2002 speech by the then First Minister Jack McConnell (BBC News 2002), although Slater and Pedersen (2009) observe that he made no clear distinction between the concepts of social justice, environmental justice and sustainable development. From that point onwards, the Scottish Executive (rebranded as the Scottish Government in 2007) approached environmental justice from both the distributive and procedural perspectives (Slater \& Pedersen 2009), although Maschewsky was critical of the lack of a clear strategy and of the Scottish Executive's practice of following an 'embedded' political approach, where environmental justice was 'smuggled' into existing programmes with 'little or no changes in targets, priorities and funding-schemes' (Maschewsky 2005, pp. 24-25).

As Slater and Pedersen (2009) point out, many of the procedural changes to Scottish legislation have reflected the Scottish Government's obligations under European law. Key here was the 1998 Aarhus Convention on Access to Information, Public Participation in Decision-Making and Access to Justice in Environmental Matters which recognised that:

\footnotetext{
${ }^{2}$ For those readers unfamiliar with the legislative situation in the United Kingdom, dramatic constitutional changes in the late 1990s saw the devolution of some legislative powers from central government in London to three new devolved bodies: the Scottish Parliament, the National Assembly for Wales and the Northern Ireland Assembly. The devolved matters on which the Scottish Parliament can pass laws include: agriculture; civil and criminal justice; education; environment; health; housing; local government; planning; social work; sport and the arts; and transport. At the time of writing, the UK is on the eve of potentially its most significant constitutional change in over 300 years: the Scottish independence referendum on 18 September 2014 may result in the end of the UK in its present form.
} 
'improved access to information and public participation in decision-making enhance the quality and the implementation of decisions, contribute to public awareness of environmental issues, give the public the opportunity to express its concerns and enable public authorities to take due account of such concerns' (United Nations Economic Commission for Europe 1998, p. 2).

As its full title implies, the Aarhus Convention is built upon three 'pillars' — access to information, public participation, and access to justice - the first two of which were the subject of European Directives in 2003. Directive 2003/4/EC was concerned with public access to environmental information, which was defined as information on:

- the state of the elements of the environment (i.e. air, water, soil, etc.) and the factors affecting these;

- the measures or activities designed to protect these elements, and the analyses and assumptions associated with these;

- reports on the implementation of environmental legislation; and

- the state of human health and safety as they are affected by the state of the elements of the environment (adapted from European Parliament and Council of the European Union 2003a, Article 2(1) ).

Directive 2003/35/EC, meanwhile, was concerned with providing for public participation in the drawing up of certain plans and programs relating to the environment (European Parliament and Council of the European Union 2003b). A proposal for a Directive on access to justice in environmental matters, which might address the third pillar of the Aarhus Convention, has yet to be adopted (European Commission 2014).

In Scotland, responses to Directive 2003/35/EC on public participation have included: the introduction of the Environmental Assessment (Scotland) Act 2005 which ensures that environmental assessments are carried out in relation to public sector development plans and programs; amendments to existing environmental impact assessment regulations (in place since 1999) which granted standing before the courts to any non-governmental organisation promoting environmental protection (Environmental Impact Assessment (Scotland) Amendment Regulations 2006); and the introduction of the Planning etc. (Scotland) Act 2006, which talks repeatedly of 'involving the public at large'. 
Meanwhile, Directive 2003/4/EC on access to environmental information led to the introduction of the Environmental Information (Scotland) Regulations 2004 (EIRs), giving the public a general right of access to environmental information held by Scottish public authorities. The EIRs came into force on 1 January 2005, the same day as Scotland introduced its new freedom of information legislation - the Freedom of Information (Scotland) Act 2002 (FOISA) — which gave people the basic right to see information held by Scottish public authorities. January 2005 was, therefore, meant to herald a new era of openness and transparency amongst government and other public bodies throughout Scotland.

The extent to which these recent consultative and openness agendas in Scotland have impacted upon the environmental and ecological justice issues relating to the Donald Trump golf course development will be discussed later. But first this paper will explore the issues surrounding the gas terminal development, which took place in a less open and participative era, and of course before the terms environmental justice and ecological justice had been conceived.

\section{'Jobs versus ducks': the gas terminal development}

In November 1972, in the midst of the North Sea oil and gas exploration boom, the British Gas Council and Total announced plans to construct a gas reception terminal on a disused airfield at Crimond, Aberdeenshire. At this stage, the developers were not forthcoming with details of their proposals: all that they would reveal was that the terminal would handle gas piped from the Frigg field, 200 miles away in the North Sea, that it would be built on a 500acre site, would cost several hundred million pounds, and would result in around 50-60 permanent jobs, although the pipelaying and construction stages would employ hundreds (Dunn 1972).

These plans were controversial, as the proposed site was adjacent to Britain's largest coastal dune lake, the Loch of Strathbeg, which had recently been designated a Site of Special Scientific Interest (SSSI) because of its natural history, particularly its ornithology (Nature Conservancy 1970). Strathbeg had long been recognised as an internationally important site for wintering geese and ducks, and, in fact, the Royal Society for the Protection of Birds (RSPB) was in the process of trying to secure various parcels of land around the loch to create a new nature reserve. The situation was further complicated by the fact that the 
Ministry of Defence (MOD) had already received clearance to build an important Royal Naval radio station on the same airfield site.

At the time, there was little history of public consultation in planning processes in Scotland, with the existing legislation — the Town and Country Planning (Scotland) Act 1969 — referring only to 'adequate publicity' and entitlement to an 'opportunity of making representations'. Indeed, Burton and Johnson (1976), in a review of public participation in planning in Scotland, noted that much confusion existed amongst planning authorities as to what exactly was expected of them. Participation in planning, they concluded, was still at an experimental stage.

This unsystematic approach to public engagement was evident during the initial, 14-day, public consultation period, where a copy of the Crimond terminal site plan could be inspected at the offices of the local planning authority, Aberdeen County Council. The lack of detail on the plan, and the short time frame in which representations could be made, angered local environmental opponents. As one pointed out:

\footnotetext{
'The plan consists simply of a map of the old airfield at Crimond, coloured red, a blue road leading into it from the west and a 'corridor' one-third of a mile wide from the airfield through the loch itself and the coastal dunes leading to the sea labelled 'possible pipeline corridor'... How can anyone be expected to make sensible representations... on the basis of such meagre information? ... How, indeed, can any responsible planning authority give planning permission in principle, on such data?' (Dunnet 1972)
}

Within a few weeks of the Crimond plans being announced, some organised opposition began. Most notable here was the formation of the North-east Environmental Liaison Group (ELG), which consisted of academics from the botany, geography and zoology departments of Aberdeen University, and representatives of various conservation groups, including the RSPB, the Scottish Ornithologists’ Club, and the Scottish Wildlife Trust (SWT). The ELG sought not only to prevent the terminal being built on the airfield site, but also to appeal for a more careful planning approach to industrial development in general across North-east Scotland. Given the lack of detail emanating from the developers, the ELG came to play a crucial role in disseminating information and advice on the potential environmental impact of the terminal being located immediately next to Strathbeg. The local and national (Scottish) press were generally sympathetic to the arguments of the ELG and afforded them significant 
column inches in which to present their case (e.g. Aberdeen Press and Journal 1972; MacDonald 1972). Members of the ELG also had an article published in the highly influential journal Nature (Bourne et al. 1973), thus ensuring that the story reached an international, scientific audience. And the County Council, perhaps realising the lack of environmental expertise within its own ranks, quickly invited the group to adopt a semiofficial advisory role, with the ELG taking part in all of the Council’s subsequent meetings with the developers.

Individuals in another new protest group, the Buchan Action Group (Buchan is the historical name for the area surrounding the town of Peterhead - see Figure 1), were instrumental in organising a public meeting, held at Crimond in February 1973, at which representatives of the Gas Council and Total appeared in order to explain their choice of the airfield site. Yet, opponents remained critical of the lack of detail from the developers. Indeed, a few days after the public meeting, the Aberdeen Evening Express, in the concluding part of an investigation into the human impact of oil and gas exploration — entitled 'People's lives matter: tell us what is going on' — argued:

\footnotetext{
'It is not good enough that the people of Buchan have so little information about the gas terminal planned for Crimond... It is not good enough when 'little man' action groups are called upon to prove big business wrong with little expertise and less money' (Ogilvie 1973).
}

Clearly, then, the systems and procedures required in order to attain some semblance of what is now known as procedural environmental justice were lacking at the time of the Crimond planning application. Aberdeen County Council was not alone in this regard: Holmes found that Scotland's planning authorities were generally ill-equipped to deal with the demands created by the oil and gas boom and by other large-scale industrial development, with one planner exclaiming:

'We've all these preservation people, conservation people... They all want us to keep them fully informed! How can we do it? How can we possibly do it?' (Holmes 1973, p. 1)

A detailed account of the full sequence of events relating to the planning application is beyond the scope of this paper. However, in April 1973, the Gas Council and Total announced that they had found an alternative site for the terminal, a few miles away at St. Fergus, in a far less environmentally sensitive area. Much to the chagrin of the ELG, though, 
the developers refused to concede victory to the conservationists, insisting that the decision to change site was driven solely by the MOD’s need for the airfield site. In a prophetic turn of phrase, the ELG declared that this did 'much less than justice to the ecologists' case' (Cummings 1973). Years later, the Gas Council continued to maintain that 'solutions acceptable to all parties could have been implemented' should the terminal have been built next to Strathbeg (Dean 1981).

A new planning application for the St. Fergus site was submitted by the Gas Council and Total in May 1973. Following another public meeting (this time arranged by the developers, rather than by local residents) and a further 14-day consultation period, no public objections were lodged. Although further concerns were expressed by the conservation lobby about a lack of detailed information on the new St. Fergus proposals (Dunn 1973), planning permission in principle was given in July 1973. Outline planning permission for the terminal plant, an administration block, heliport and access roads was then granted in October 1973, subject to some conditions, most significantly that the developers consult and co-operate with the County Council and the SWT in ensuring that the local flora and fauna be conserved, that public access to the foreshore and dunes be preserved, and that the foreshore and dunes be returned to their former state once the pipelines from the North Sea had been laid through them (Aberdeen County Council 1973).

In order to confirm that these planning conditions were being met, a committee was established, under the aegis of the Gas Council, to monitor the construction of the terminal and its impact on the coastal environment. In the initial stages of the terminal's development, this committee was effectively an offshoot of the ELG, comprising Aberdeen University academics and representatives of the developers, the Council, and various regional conservation bodies. As the terminal subsequently expanded, ${ }^{3}$ and as additional pipelines were laid through the dunes, the original committee was replaced by the St. Fergus Dunes Management Committee in 1988, and renamed the St. Fergus Coastal Environment Committee in 1998. In later years, the regional conservation bodies discontinued their membership, 'being content that their interests would be served by the membership or by consultation processes when required' (Ritchie 1997, p. 10). Throughout, the Committee, in

\footnotetext{
${ }^{3}$ The first full environmental impact assessment did not take place until 1976 when the company Shell proposed to build its own gas reception facilities on the St. Fergus site (Cremer \& Warner 1977).
} 
its various guises, has monitored and assessed the impact of the terminal complex on the local wildlife, vegetation, landform, soil, water quality and drainage.

Looking back over the construction and subsequent expansion of St. Fergus, has ecological justice been done? Some of the earliest published assessments, written by members of the Dunes Management Committee (e.g. Ritchie 1980; Ritchie \& Gimingham 1989), indicated that the landform and hydrology had been restored satisfactorily, although efforts at revegetation had met with mixed success. In a major scientific volume published to mark 25 years of the Committee, which included papers on the hydrology, vegetation, and the bird and insect life of the St. Fergus dunes, Ritchie (1997, p. 15) reported:

\footnotetext{
'Another pragmatic approach to the measurement of success is to state that in relation to any environmental issue related to the pipeline landfalls at St. Fergus there have been no public or local enquiries, no complaints of substance by local or national regulatory bodies and no controversies as engendered by official or voluntary environmental or ecological bodies.'
}

Perhaps ironically, the terminal itself became something of a haven for birdlife. A flat-roofed building on the site housed Britain's first roof-nesting common terns. The security fences surrounding the complex prevented four-legged predators such as foxes entering the area, allowing ground-nesting birds to flourish (Tomlinson 1990), although when stoats and weasels subsequently negotiated the fences many of the ground-based nests were destroyed (Bourne 2005). The terminal operators have won a number of environmental awards (e.g. Aberdeen Evening Express 2007; Shell World UK 2013); and, in terms of ecological justice being seen to be done, they continue to make information on their environmental policies, systems and performance publicly available (e.g. Total E\&P UK 2011).

To summarise, then, the Gas Council and Total, in the earliest planning stages, paid scant regard to providing information on the environmental issues associated with building the gas terminal next to Strathbeg, and on how they might address these issues. However, once a new location for the terminal had been announced, and as construction and operation of the terminal progressed, then information on its potential and actual environmental impact was more forthcoming, albeit with significant input from concerned local conservationists. In short, it might be said that procedural environmental justice and ecological justice were eventually done. The extent to which the same can be said about Donald Trump’s golf resort will be explored in the next part of this paper. 


\section{'Livelihoods before liverwort': Trump's golf course development}

The story of Trump's bid to build the 'the greatest golf course anywhere in the world' is a long and complex one. This paper will, therefore, relate some of the key events only. The $£ 300$ million project on the Menie Estate in Aberdeenshire — Trump International Golf Links, Scotland (TIGLS) — was announced initially in March 2006, and was to include two championship courses, a 5-star hotel, and a mixed residential development. Crucially, though, Trump also warned that he would abandon his plans if proposals for a nearby 33-turbine offshore windfarm were to proceed, arguing that this would spoil the sea views from his resort (Johnston \& Smith 2006). Trump’s plans immediately attracted polarised views: business and tourism groups welcomed the news and the estimated economic benefits the resort would bring to the region; while environmental bodies expressed concerns, particularly as the course would be built partly on an existing SSSI, including a rare, dynamic, shifting dune system ${ }^{4}$.

In November 2006, Trump submitted his outline planning application to the local planning authority, Aberdeenshire Council, indicating that it would now be a $£ 1$ billion project, and would include the two courses, a clubhouse, a 450-room hotel, a golf academy and turf research centre, an accommodation block for 400 employees, almost 1,000 holiday homes and 500 residential properties. As Trump's proposed development was subject to the Environmental Impact Assessment (Scotland) Regulations 1999 (such regulations, applying to certain types of planning applications, have been in place in Scotland since 1988), TIGLS was statutorily obliged to provide an environmental assessment report. This 316-page report (plus several appendices) was submitted in March 2007 and acknowledged that there would be 'significant adverse changes' to the SSSI (Ironside Farrar 2007, p. 305), but also promised various 'mitigation measures' to 'maintain and enhance as much natural interest as possible' (pp. 309-316). These promises were frequently accompanied by verbal assurances from Trump himself, who proclaimed, for example: 'because we are stabilising the land, the environment will be much superior when we are finished’ (Ross 2007).

\footnotetext{
${ }^{4}$ Opposition to the golf resort was based mostly on environmental grounds until May 2009, when TIGLS raised the prospect of pursuing compulsory purchase orders to acquire four residential properties on the Menie Estate. The threat of compulsory purchase was finally lifted in January 2011.
} 
In complete contrast to the Crimond gas terminal application in the 1970s, the TIGLS environmental assessment and other supporting documentation (including economic and transport assessments) was made readily available to the public, online, at council offices and public libraries, and at a series of public exhibitions and meetings held throughout the area. The full planning application was subject to the by now standard 28-day public consultation period, but, owing to the 'complexities' of the proposals, conservation bodies including the RSPB, the SWT, and Scottish Natural Heritage (SNH) were allowed more time in which to respond (Urquhart 2007). Aberdeenshire Council also continued to accept representations from the wider public until November 2007, meaning that the consultation period was effectively eight-months long. One of the key elements of procedural environmental justice — the right to participate in environmental decision-making — was, therefore, to the fore during the TIGLS planning application process.

Although the Council's planners had recommended the approval of the TIGLS proposals, arguing that 'this is an occasion where the social and economic benefits are of national importance and that these do override the adverse environmental impacts' (Aberdeenshire Council 2007a, paragraph 6.55), the application was controversially rejected by the Council's infrastructure committee in November 2007, largely because of these adverse impacts on the SSSI and because of concerns about the inclusion of commercial housing on land not allocated for that purpose in the local development plan (Aberdeenshire Council 2007b). A few days later, however, the Scottish Government called in the application, stating that it 'raises issues of importance that require consideration at a national level' (Scottish Government 2007). Following a public inquiry in the summer of 2008, the Scottish Government decided to grant outline planning permission for the resort in November 2008, affirming that 'there was significant economic and social benefit to be gained from this project' (Scottish Government 2008a).

This outline planning permission was subject to 46 conditions that had been recommended by the public inquiry reporters (see Scottish Government 2008b, Appendix 1B, pp. 247-260), several of which focused on environmental issues, including:

- $\quad$ agreed methods of stabilising the dunes;

- $\quad$ safeguarding the foraging routes of otters and badgers; 
- a goose management scheme;

- provisions for bats and barn owls in the built elements of the resort;

- a scheme for monitoring local water quality; and, importantly,

- the appointment of a suitably qualified Ecological Clerk of Works (to be funded by the developer) to ensure that all works relating to the ecological interests of the site are undertaken appropriately.

The final report of the public inquiry also noted an existing agreement between TIGLS and Aberdeenshire Council to create an independent Menie Environmental Management Advisory Group (MEMAG), the idea for which had been first mooted in the TIGLS environmental assessment report (Ironside Farrar 2007, Appendix 6-6). MEMAG was to be funded by TIGLS and was to be based on the St. Fergus Dunes Management Committee model, with a remit to provide advice to TIGLS and the Council on:

- environmental management and operation 'best practice';

- monitoring the local environment;

- minimising unanticipated adverse changes; and, significantly,

- complying fully with the relevant conditions attached to the outline planning permission (Scottish Government 2008b, p. 264).

Initial preparatory work on the Menie Estate began in October 2009, and in February 2010 TIGLS submitted the final masterplan for the resort, including an 89-page (plus appendices) environment management plan (STRI Ecology \& Environment 2010). As with the original application, this was subject to a 28-day consultation period, and the documentation was made publicly available, online and at a special exhibition. Following approval of the masterplan, construction work on the first championship course commenced in June 2010. That course, together with a temporary clubhouse, opened in July 2012, but plans to build the rest of the resort (the hotel, housing, etc.) were recently abandoned after Trump failed in a legal challenge to prevent the offshore windfarm (by now an 11-turbine project) being built (Urquhart 2014).

How, then, have the Ecological Clerk of Works (ECoW) and MEMAG fared in monitoring the environmental impact of the construction work carried out on the course, and in ensuring 
that ecological justice has been done? The ECoW — a commercial environmental consultancy — submitted 21 site visit reports to Aberdeenshire Council between December 2009 (just after preparatory work had begun) and June 2012 (just before the golf course opened for business). These documents can be found (with some difficulty) on the Council's website (see Aberdeenshire Council 2012) and are generally positive, in that they confirm that TIGLS and its contractors did largely comply with planning requirements but also note occasions when planning conditions were not being adhered to. ${ }^{5}$ For example, they highlighted any earthworks that occurred outside the agreed course layout, and any deviations from agreed construction traffic access routes; they talked of the protocols followed when earthworks and vegetation clearance took place within the bird nesting season; and they provided evidence of the ECoW prohibiting vehicles stopping in an area adjacent to a breeding gull colony, and having ordered the suspension of planting work taking place too close to a badger sett. Despite this, opponents of the golf course have questioned the impartiality of a TIGLS-funded ECoW:

'Who was in charge of the environment? It seems paid Trump personnel... How can a system allow a developer to be his own watchdog?’ (Kelly 2013a)

It should also be noted that the $21 \mathrm{ECoW}$ reports appear not to have been made publicly available online until November 2012, some months after the course had opened. The public at large, therefore, had little opportunity to assess the environmental effects of the construction work as it progressed. Opponents have also cast doubts on the reliability of the environmental information that was provided by Aberdeenshire Council during the construction phase. For example, Kelly (2012) had written directly to the ECoW on environmental planning matters in 2011, but claimed that the information received in return (relating to the removal and burial of trees on the site, and the construction of earth bunds close to residents’ properties) directly contradicted that obtained from local residents, as well as footage from a documentary film about the golf course development entitled You've Been Trumped (Baxter 2011).

With regard to MEMAG, meanwhile, although TIGLS declared that the Group had prepared 'glowing reports' on the environmental care taken with the course (Pauling 2012), the extent to which it has been successful in meeting its remit is currently unclear, largely because it

\footnotetext{
${ }^{5}$ It should be noted that TIGLS was subsequently criticised by Aberdeenshire Council for the number of retrospective planning conditions it made in order to remedy 'breaches of planning control' (Edwards, R. 2013a).
} 
appears to have ceased operation. It is known that MEMAG met for the first time in December 2009, and that it consisted of representatives of TIGLS, Aberdeenshire Council, a local community council, and the Scottish Government's conservation and environmental watchdogs, SNH and the Scottish Environment Protection Agency (SEPA) (Davidson 2009). By May 2012, however, members were expressing concerns about the absence of TIGLS representation at recent meetings (see Kelly 2013b). MEMAG appears to have met for the last time in January 2013, and the Council claimed to have been carrying out a review of the Group's remit in the summer of that year (Edwards, R. 2013b). By August 2013 all minutes of its meetings had been removed from its website at www.memag.org.uk (see Kelly 2013a), and by February 2014 its entire website had disappeared.

Recent efforts by the current author to establish the fate and future of MEMAG have so far met with mixed success. These efforts have largely taken the form of freedom of information requests to the Group's constituent members. SEPA ignored the request completely; SNH suggested that contact be made with the TIGLS legal team; and the TIGLS legal advisor in Scotland simply mentioned the decision to suspend further development at Menie, without explaining why TIGLS had effectively played no part in MEMAG for almost two years. Aberdeenshire Council, at the third time of asking, eventually acknowledged that there is an obligation for MEMAG to continue, and that they had contacted Trump's agents with a view to conducting a review of the Group. Clearly, then, the existence and effective operation of MEMAG has been reliant on the whims (and, of course, the finance) of TIGLS. As such, the ‘independence and scientific integrity’ promised by TIGLS in order to ensure the 'ongoing maintenance of the environment and its ecology' (Ironside Farrar 2007, Appendix 6-6) has been lacking.

The present author is not the only one to have queried the status of MEMAG. The online citizen newspaper Aberdeen Voice has run several articles by opponents of the Trump development, a number of which have highlighted the apparent demise of MEMAG (e.g. Kelly 2013a, 2013b, 2013c). Aberdeen Voice has also published articles which suggest that environmental care may not always have been taken during and after the construction of the golf course. For example, Edwards writes:

'Piles of rubbish are burnt regularly, and heaps of grass cuttings have plastic chemical containers buried in them. Attempts have been made to cover the evidence with sand' (Edwards, S. 2013) 
In the case of Trump's golf course, then, it is unclear if ecological justice has been done. Despite systematic monitoring procedures having been included as part of the planning conditions, the responsible planning authority, Aberdeenshire Council, has not been rigorous in ensuring that these conditions are enforced. And despite a supposed culture of openness and transparency amongst public authorities in Scotland, the Council and the other bodies involved in the environmental monitoring process have been unwilling to impart information in a full and timely manner.

With further regard to information access, responsibility for the enforcement and promotion of Scotland's EIRs and the FOISA lies with the Scottish Information Commissioner (SIC), and in a special report to the Scottish Parliament the first (and outgoing) Commissioner highlighted the ‘wealth of information' relating to Trump’s Menie development released under the FOISA by the Scottish Government in 2008 (Scottish Information Commissioner 2012, p. 7). However, close examination of these documents (see Scottish Government 2008c) reveals that $20 \%$ were the subject of considerable redaction which effectively rendered them meaningless. It is also fair to say that some of Trump's opponents remain unconvinced that all pertinent information relating to the golf course project has found its way into the public domain (e.g. Kelly 2013d). Indeed, at the time of writing (June 2014), the SIC has completed six investigations into EIRs or FOISA applications relating to the golf resort, and in each case has found that the public authorities concerned have failed to comply fully with the legislation (see Scottish Information Commissioner 2014). The SIC is also currently considering an appeal made by the present author, after the Scottish Government declined to provide information on those 'third parties' (i.e. individual citizens) who made representations to the 2008 public inquiry on the Menie planning application.

Clearly, then, not all public bodies involved with the Trump development have fully embraced the spirit of openness and transparency. Much of the information relating to the resort has been released almost under duress, following interventions from the SIC, rather than being provided as a matter of course. Why this should be the case must remain conjecture. Perhaps there are concerns that the release of information might shed light on embarrassing or damaging political machinations. Perhaps they have been too readily influenced by Trump, who has developed a reputation for being litigious (e.g. Alter 2013) and something of a 'cavalier and unpleasant bully’ (Scotsman 2012) in his business dealings. 
Or perhaps the TIGLS case simply reflects, in microcosm, wider attitudes towards freedom of information amongst officialdom in Scotland, for the SIC has recently expressed concerns about a rise in the number of appeals following a lack of response to FOISA requests:

'Eight years on from the implementation of FOI, we would expect to see authorities becoming more effective in the technical aspects of request handling, not less so. A failure to respond is, quite simply, a failure to respect the requester's statutory rights...' (Scottish Information Commissioner 2013, p. 10)

\section{Conclusions}

This paper has explored the relationship between public access to information and procedural environmental justice and ecological justice through a comparison of two controversial developments on the coast of North-east Scotland: the building of a North Sea gas reception terminal by the British Gas Council and Total some forty years ago, and the more recent construction of Donald Trump's golf course. Using these two projects as examples, can it be argued that environmental and ecological justice are now more attainable in this current era of supposed transparency and public engagement in planning procedures, than in the more secretive and less participative 1970s?

Certainly, at the planning application stage, information on the potential environmental impact of the TIGLS golf resort has been more readily obtainable, compared with that provided by the Gas Council and Total forty years earlier. Planning permission to build the gas terminal at Crimond was sought within just 14 days and was based on 'the sketchiest of information' (Dunnet 1974, p. 14), and the one public meeting that took place was arranged at the behest of concerned residents rather than by the planning authority or the developers. Forty years ago, anyone wishing to participate in the initial planning process had to rely on information provided by environmental opponents of the terminal, rather than by the applicants themselves. Even when attention had switched to the far less environmentally sensitive St. Fergus site, detailed plans were not immediately forthcoming from the developers and representations were again expected within 14 days. In complete contrast, the full TIGLS application was effectively subject to an eight-month consultation period, and was supported by a lengthy (and, of course, mandatory) environmental assessment report, which was made widely available to any interested parties, both online and offline. The subsequent masterplan for the resort also included a detailed environment management plan. In this regard, information provision has played an important role in ensuring that procedural 
environmental justice has been further to the fore during the Trump resort planning application than in the case of the gas terminal four decades earlier.

During and after the construction stage, though, when considering the provision of information on whether or not the developments have met the environmental planning conditions - and therefore establishing whether or not ecological justice has been done the situation with the St. Fergus gas terminal has been far clearer than with the TIGLS resort. Over the last 40 years, the various incarnations of the St. Fergus Dunes Management Committee have continually monitored the impact of the terminal, and have reported publicly on what has generally been regarded as an environmental success story. With Trump's golf resort, however, although the reports of the ECoW suggest that environmental care was generally taken during the construction of the first course, these were not made publicly available until some time after the course had been completed. And the objectivity of the ECoW - a consultancy company funded solely by TIGLS - has been challenged by some of Trump's more sceptical opponents, who have also offered alternative views on the environmental effects of the course construction. Meanwhile, the unexplained demise of MEMAG and the removal from the public eye of all records relating to the Group, has meant that the environmental impact of the golf course, in its post-construction, operational stage, remains shrouded in mystery.

Bearing these points in mind, there is little evidence to indicate that ecological justice is more attainable in this current age of supposed open government. Despite the existence of freedom of information legislation, there remain a number of unanswered questions concerning the environmental effects of building 'the greatest golf course anywhere in the world'.

\section{References}

Aberdeen County Council 1973, Minutes of Countryside Committee and Planning Committee meetings, 5 October, held by Aberdeen City and Aberdeenshire Archives.

Aberdeen Evening Express 2007, 'Major eco award to gas plant', Aberdeen Evening Express, 8 December, p. 20.

Aberdeen Press and Journal 1972, 'North Sea gas plan opposed: preservationists call for inquiry on Crimond industrial project', Aberdeen Press and Journal, 22 December, p. 9.

Aberdeenshire Council 2007a, Formartine Area Committee Report - 18 September 2007, http://www.aberdeenshire.gov.uk/committees/files_meta/802572870061668E80257352004E6 138\%5C2006-4605.pdf Accessed 30 June 2014. 
Aberdeenshire Council 2007b, Infrastructure Services Committee, Woodhill House, Aberdeen, 29 November, 2007, http://www.aberdeenshire.gov.uk/committees/files_meta/802572870061668E802573C50042 E4EF/291107isc.pdf Accessed 30 June 2014.

Aberdeenshire Council 2012, Ref: APP/2006/4605,

http://www.aberdeenshire.gov.uk/planning/apps/detail.asp?ref no=APP/2006/4605 Accessed 30 June 2014.

Alter, C. 2013, ‘Trump’s taste of his own medicine’, Time, 26 August, http://nation.time.com/2013/08/26/trumps-taste-of-his-own-medicine/ Accessed 27 June 2014.

Baxter, A. 2011, You've Been Trumped, Film, Montrose Pictures.

Baxter, B.H. 2000, 'Ecological justice and justice as impartiality', Environmental Politics, vol. 9, no. 3, pp. 43-64. doi: http://dx.doi.org/10.1080/09644010008414537

BBC News 2002, 'McConnell delivers green pledge', 18 February, http://news.bbc.co.uk/1/hi/scotland/1824752.stm Accessed 23 June 2014.

Bourne, W.R.P. 2005, 'Windfarms a threat? - or can birds adapt?', Scottish Bird News, no. 77, p. 16.

Bourne, W.R.P., Gimingham, C.H., Morgan, N.C. \& Britton, R.H. 1973, 'The Loch of Strathbeg', Nature, vol. 242, no. 5393, pp. 93-95. doi: http://dx.doi.org/10.1038/242093a0

Bullard, R.D. 1999, 'Building just, safe, and healthy communities', Tulane Environmental Law Journal, vol. 12, pp. 374-404.

Burton, A.W. \& Johnson, R. 1976, Public Participation in Planning: a Review of Experience in Scotland, The Planning Exchange, Glasgow.

Church, M. 2011, Tipping the Scales: Complying With the Aarhus Convention on Access to Environmental Justice, http://www.foe-scotland.org.uk/tippingthescales Accessed 24 June 2014.

Cremer \& Warner 1977, The Environmental Impact of the Natural Gas Terminal at St. Fergus, Cremer \& Warner, London.

Cummings, B. 1973, ‘Crimond - N.E. group’s concern', Aberdeen Press and Journal, 8 May, p. 2.

Davidson, R. 2009, 'Move to minimise project's impact', Aberdeen Press and Journal, 12 December, p. 14.

Dean, F.E. 1981, 'St Fergus: visual and design considerations' in Cairns, W.J. and Rogers, P.M. (eds), Onshore Impacts of Offshore Oil, Applied Science Publishers Ltd., Barking, pp. 145-153.

Dunn, H. 1972, 'Multi-million gasfield plan put to Aberdeenshire', The Scotsman, 29 November, p. 7.

Dunn, H. 1973, 'No opposition to gas plant at St Fergus', The Scotsman, 17 July, p. 6.

Dunnet, G. 1972, 'Crimond site rush deplored', Aberdeen Press and Journal, 9 December, p. 6.

Dunnet, G.M. 1974, 'Impact of the oil industry on Scotland's coasts and birds', Scottish Birds, vol. 8, no. 1, pp. 3-16.

Edwards, R. 2013a, 'Trump criticised for planning breaches', Sunday Herald, 16 June, p. 16.

Edwards, R. 2013b, 'Trump war two', Sunday Herald, 18 August, p. 22.

Edwards, S. 2013, 'The Trump has landed', Aberdeen Voice, 7 June, http://aberdeenvoice.com/2013/06/the-trump-has-landed/ Accessed 30 June 2014.

Environmental Assessment (Scotland) Act 2005, http://www.legislation.gov.uk/asp/2005/15/contents Accessed 24 June 2014

Environmental Impact Assessment (Scotland) Regulations 1999, http://www.legislation.gov.uk/ssi/1999/1/contents/made Accessed 30 June 2014.

Environmental Impact Assessment (Scotland) Amendment Regulations 2006, http://www.legislation.gov.uk/ssi/2006/614/contents/made Accessed 25 June 2014,

Environmental Information (Scotland) Regulations 2004, http://www.legislation.gov.uk/ssi/2004/520/contents/made Accessed 30 June 2014. 
European Commission 2014, The EU \& the Aarhus Convention: in the EU Member States, in the Community Institutions and Bodies, http://ec.europa.eu/environment/aarhus/legislation.htm Accessed 24 June 2014

European Parliament and Council of the European Union 2003a, 'Directive 2003/4/EC of the European Parliament and of the Council of 28 January 2003 on public access to environmental information and repealing Council Directive 90/313/EEC', Official Journal of the European Union, L 41, 14 February, pp. 26-32, http://eurlex.europa.eu/LexUriServ/LexUriServ.do?uri=OJ:L:2003:041:0026:0032:EN:PDF Accessed 30 June 2014.

European Parliament and Council of the European Union 2003b, 'Directive 2003/35/EC of the European Parliament and of the Council if 26 May 2003 providing for public participation in respect of the drawing up of certain plans and programmes relating to the environment and amending with regard to public participation and access to justice Council Directives 85/337/EEC and 96/61/EC', Official Journal of the European Union, L 156, 25 June, pp. 1724, http://eur-lex.europa.eu/legalcontent/EN/TXT/PDF/?uri=CELEX:32003L0035\&from=EN Accessed 24 June 2014.

Faber, D. \& McCarthy, D. 2001, 'The evolving structure of the environmental justice movement in the United States: new models for democratic decision-making', Social Justice Research, vol. 14, no. 4, pp. 405-421. doi: http://dx.doi.org/10.1023/A:1014602729040

Freedom of Information (Scotland) Act 2002, http://www.legislation.gov.uk/asp/2002/13/contents Accessed 30 June 2014.

Holmes, A. 1973, 'Sands of time are running out for the planners', The Scotsman, 12 May, weekend supplement p. 1.

Ironside Farrar 2007, Golf \& Leisure Resort, Menie Estate, Balmedie, Aberdeenshire: Environmental Statement, http://www.aberdeenshire.gov.uk/plann4605ing/apps/detail.asp?ref no=APP/2006/4605 Accessed 30 June 2014

Johnston, J. \& Smith, G. 2006, 'Wind may be hazard in Trump’s plans to build £300m golf resort', The Herald (Glasgow), 1 April, p. 3.

Kelly, S. 2012, 'Bully for you: Trump threatens suit against filmmaker', Aberdeen Voice, 24 October, http://aberdeenvoice.com/2012/10/bully-for-you-trump-threatens-suit-against-filmmaker/ Accessed 30 June 2014.

Kelly, S. 2013a, 'Menie: the case for a public inquiry - part 2', Aberdeen Voice, 27 August http://aberdeenvoice.com/2013/08/menie-case-public-inquiry-part-2/ Accessed 30 June 2014.

Kelly, S. 2013b, 'The Menie Estate: from SSSIs to bluegrass country', Aberdeen Voice, 25 February, http://aberdeenvoice.com/2013/02/the-menie-estate-from-sssis-to-bluegrass-country/ Accessed 30 June 2014.

Kelly, S. 2013c, 'Trump golf course public consultation - my experience', Aberdeen Voice, 23 August, http://aberdeenvoice.com/2013/08/trump-golf-course-public-consultation-myexperience/ Accessed 30 June 2014.

Kelly, S. 2013d, 'Scottish Enterprise, Trump and Menie - business as usual', Aberdeen Voice, 10 June, http://aberdeenvoice.com/2013/06/scottish-enterprise-trump-and-menie-business-as-usual/ Accessed 30 June 2014

Kirk, T. 2006, 'Trump reveals £300m north-east golf dream’, Aberdeen Press and Journal, 31 March, p. 1.

Low, N. \& Gleeson, B. 1998, Justice, Society and Nature, Routledge, London.

MacDonald, G. 1972, 'North-East group fight to protect environment', Glasgow Herald, 22 December, p. 5. 
Maschewsky, W. 2005, Environmental Justice in Scotland - Just Words? A View From Outside, http://www.foe-scotland.org.uk/aviewfromoutside Accessed 24 June 2013

McGurty, E.M. 1997, 'From NIMBY to civil rights: the origins of the environmental justice movement', Environmental History, vol. 2, no. 3, pp. 301-323. doi: http://dx.doi.org/10.2307/3985352

Nature Conservancy 1970, Sites of Special Scientific Interest: Loch of Strathbeg - Aberdeenshire, Letter announcing proposals to designate Strathbeg as a SSSI, sent by the Nature Conservancy to a Crimond landowner on 17 November 1970, held by RSPB Scotland, Aberdeen.

Ogilvie, G. 1973, 'People’s lives matter: tell us what is going on', Aberdeen Evening Express, 9 February, p. 8.

Parris, C.L., Hegtvedt, K.A., Watson, L.A. \& Johnson, C. 2014, 'Justice for all? Factors affecting perceptions of environmental and ecological injustice’, Social Justice Research, vol. 27, no. 1, pp. 67-98. doi: http://dx.doi.org/10.1007/s11211-013-0200-4

Pauling, T. 2012, ‘Councillors snub Trump invitation’, Aberdeen Press and Journal, 16 June, p. 8.

Pezzullo, P.C. 2001, 'Performing critical interruptions: stories, rhetorical invention, and the environmental justice movement', Western Journal of Communication, vol. 65, no. 1, pp. 125. doi: http://dx.doi.org/10.1080/10570310109374689

Planning etc. (Scotland) Act 2006. http://www.legislation.gov.uk/asp/2006/17/contents Accessed 30 June 2013.

Ritchie, W. 1980, 'Environmental aspects of oil and gas pipeline landfalls in northeast Scotland', Proceedings of the Seventeenth Coastal Engineering Conference, March 23 to 28, 1980, Sydney, Australia, Volume III, American Society of Civil Engineers, New York, pp. 29382954.

Ritchie, W. 1997, 'The St. Fergus gas terminals: the structural and environmental context of monitoring' in Ritchie, W. \& Kingham, L (eds), The St. Fergus Coastal Environment: Monitoring and Assessment of the North Sea Gas Terminals at St. Fergus, Aberdeen University Research \& Industrial Services Limited, Aberdeen, pp. 1-15.

Ritchie, W. \& Gimingham, C.H. 1989, 'Restoration of coastal dunes breached by pipeline landfalls in north-east Scotland', Proceedings of the Royal Society of Edinburgh, Section B, vol. 96, pp. 231-245.

Ross, J. 2007, 'Trump: I could lose millions over golf plan', The Scotsman, 9 October, p. 13.

Scandrett, E., Dunion, K. \& McBride, G. 2000, 'The campaign for environmental justice in Scotland', Local Environment, vol. 5, no. 4, pp. 467-474. doi: http://dx.doi.org/10.1080/713684885

Schlosberg, D. 2004, 'Reconceiving environmental justice: global movements and political theories', Environmental Politics, vol. 13, no. 2, pp. 517-540. doi: http://dx.doi.org/10.1080/0964401042000229025

Schlosberg, D. 2007, Defining Environmental Justice: Theories, Movements, and Nature, Oxford University Press, Oxford. doi: http://dx.doi.org/10.1093/acprof:oso/9780199286294.001.0001

Scholsber, D. 2013, 'Theorising environmental justice: the expanding sphere of a discourse', Environmental Politics, vol. 22, no. 1, pp. 37-55. doi: http://dx.doi.org/10.1080/09644016.2013.755387

Scotsman 2012, 'Leader: Trump's swipe at wind farm site puts him in the rough', 10 February, p. 32.

Scottish Government 2007, Proposed Golf Course at Menie Estate, News release, 4 December, http://www.scotland.gov.uk/News/Releases/2007/12/05082758 Accessed 30 June 2014.

Scottish Government 2008a, Trump Golf Resort Gets Go Ahead, News release, 3 November, http://www.scotland.gov.uk/News/Releases/2008/11/03123709 Accessed 28 March 2014. 
Scottish Government 2008b, Decision on the Menie Estate Planning Application by Trump International Golf Links, Scotland: Report of the Public Local Inquiry, http://www.scotland.gov.uk/Resource/Doc/212607/0067709.pdf Accessed 30 June 2014.

Scottish Government 2008c, Information Regarding the Menie Estate Planning Application by Trump International Golf Links, Scotland, http://www.scotland.gov.uk/Publications/1997/03/17133808/0 Accessed 30 June 2014.

Scottish Information Commissioner 2012, Informing the Future: the State of Freedom of Information in Scotland, http://www.itspublicknowledge.info/nmsruntime/saveasdialog.aspx?lID=5266\&sID=5972 Accessed 30 June 2014.

Scottish Information Commissioner 2013, 2012/13 Annual Report: Upholding the Right to Know, http://www.itspublicknowledge.info/home/SICReports/AnnualReport201213.aspx Accessed 30 June 2014.

Scottish Information Commissioner 2014, Decisions, http://www.itspublicknowledge.info/ApplicationsandDecisions/Decisions/Decisions.php Accessed 30 June 2014.

Shell World UK 2013, 'Clean, lean and green', Autumn, pp. 19-20, http://s00.staticshell.com/content/dam/shell-new/local/country/gbr/downloads/pdf/swuk-autumn-2013.pdf Accessed 30 June 2014.

Slater, A. \& Pedersen, O.W. 2009, 'Environmental justice: lessons on definition and delivery from Scotland', Journal of Environmental Planning and Management, vol. 52, no. 6, pp. 797-812. doi: http://dx.doi.org/10.1080/09640560903083749

Stephens, T. 2003, 'An overview of environmental justice', Thomas M. Cooley Law Review, vol. 20, no. 2, pp. 229-247.

STRI Ecology \& Environment 2010, Trump International Golf Links Scotland: Environmental Management Plan, https://www.aberdeenshire.gov.uk/planning/apps/detail.asp?ref_no=APP/2010/0423 Accessed 31 March 2014.

Tomlinson, D. 1990, 'Terns for the better', Country Life, vol. 184, no. 27, p. 131.

Total E\&P UK 2011, St Fergus Environmental Statement 2011, http://www.uk.total.com/activities/documents/StFergus2011.pdf Accessed 30 June 2014.

Town and Country Planning (Scotland) Act 1969, http://www.legislation.gov.uk/ukpga/1969/30/contents Accessed 30 June 2014.

United Nations Economic Commission for Europe 1998, Convention on Access to Information, Public Participation in Decision-Making and Access to Justice in Environmental Matters, Done at Aarhus, Denmark, on 25 June 1998, http://www.unece.org/fileadmin/DAM/env/pp/documents/cep43e.pdf Accessed 30 June 2014

Urquhart, F. 2007, 'Protests muted as Trump's golf plans attract just 60 comments', The Scotsman, 3 May, p. 8.

Urquhart, F. 2014, 'Defeated Trump turns his back on Scotland', The Scotsman, 12 February, p. 1. 